Article

\title{
Evaluating Water Resource Accessibility in Southwest China
}

\author{
Tao Li ${ }^{1,2}$, Sha Qiu ${ }^{1,2}$, Shuxin Mao ${ }^{3} \mathbb{D}$, Rui Bao ${ }^{1,2}$ and Hongbing Deng ${ }^{1, *}$ \\ 1 State Key Laboratory of Urban and Regional Ecology, Research Center for Eco-Environmental Sciences, \\ Chinese Academy of Sciences, Beijing 100085, China \\ 2 University of Chinese Academy of Sciences, Beijing 100049, China \\ 3 School of Economics and Management, Shanxi University of Science \& Technology, Xi'an 710021, China \\ * Correspondence: denghb@rcees.ac.cn; Tel.: +86-010-6284-9112
}

Received: 18 July 2019; Accepted: 14 August 2019; Published: 16 August 2019

check for updates

\begin{abstract}
The accessibility, quantity, and quality of water resources are the basic requirements for guaranteeing water resource security. Research into regional water resource accessibility will contribute to improving regional water resource security and effective water resource management. In this study, we used a water resource accessibility index model considering five spatial factors to evaluate the grid-scale water resource accessibility and constructed the spatial pattern of water resource accessibility in Southwest China. Then, we analyzed the coupling coordination degree between county-level water resource accessibility and eco-socio-economic water demand elements. The water resource accessibility showed obvious regional differences, and the overall trend gradually decreased from Southeast to Northwest. The coupling coordination degree between county-level water resource accessibility and eco-socio-economic water demand elements was between 0.26 and 0.84 , and was relatively low overall, whereas the counties (districts) with high coordination, moderate coordination, low coordination, reluctant coordination, and incoordination accounted for $0.92 \%$, $5.31 \%, 21.06 \%, 59.71 \%$, and $13.00 \%$ of total counties (districts), respectively. Therefore, the Southwest region needs to further strengthen the construction of its agricultural irrigation facilities, protect the water resources, and coordinate the relationship between water resource management and water demand elements to comprehensively guarantee regional sustainable development.
\end{abstract}

Keywords: water resource accessibility; spatial pattern; coupling coordination degree; water resource management; Southwest China

\section{Introduction}

Water resources are essential for maintaining the sustainable development of eco-socio-economic systems [1,2]. However, due to climate change, economic growth, population increase, and improper water resource management, many environmental problems, such as serious water pollution, the deterioration of the water environment, and an increased contradiction between water supply and demand, have become increasingly severe, creating strategic problems worldwide [3-7]. The United Nations (UN) estimates that more than one-third of the population on the planet will face a freshwater crisis by 2030 [8], and residents in regions with relatively abundant water resources will still have to spend time and energy to obtain water resources, which not only increases their living costs but also impacts health $[9,10]$. Therefore, whether people living in different regions can easily and fairly obtain sufficient water resources to meet their water demand has become a hot topic for academics and policymakers.

Accessibility is a broadly accepted concept in various scientific fields such as urban planning, transportation planning, and geography [11], and was initially used to measure potential interaction 
opportunities in transportation networks [12]. As research progressed, accessibility was defined as the difficulty in reaching a destination from a given location [13]. There are two main manifestations of accessibility: The number of opportunities or benefits that can be obtained within a given time or distance, and the amount of spatial resistance that needs to be overcome to reach a destination $[14,15]$. Therefore, the measurement of accessibility depends primarily on the spatial distribution of potential destinations and the spatial resistance that needs to be overcome to reach each destination $[16,17]$. The former is mainly measured by quantity or quality, reflecting the attractiveness of the destination, and the latter is mainly measured by indicators such as time, distance, or cumulative cost, reflecting the convenience of reaching the destination $[17,18]$.

The quantity, quality, and accessibility of water resources are the basic requirements for ensuring water resource security $[19,20]$. However, the existing water resource evaluations mostly focus on the assessment of water quality and water quantity [21-25], but less attention has been paid to water resource accessibility [10,26-29]. Water resource accessibility refers to the difficulty of obtaining water resources from water sources [30], which is the fundamental factor determining the quantity, quality, and the efficiency of the water supply. Water resource accessibility is essential for human well-being, economic development, and ecological maintenance [31] and includes both spatial accessibility and time accessibility $[10,28]$, often measured by indicators such as water intake distance (Euclidean distance, cost distance, path distance, etc.) and water collection time (shortest distance time, shortest path time, self-report time, etc.) [32-34]. However, these indicators ignore the impact of water quantity and various spatial resistance factors. Therefore, some development space remains within the existing quantitative research for the examination of water resource accessibility, and the quantitative methods need to be further improved.

Southwest China is the source and upstream of many rivers, and is also an important ecological barrier zone. It plays a key role in maintaining the ecological and socio-economic security of East China, South China, and even Southeast Asia [35]. The region has abundant rainfall and a large amount of water resources. However, due to the uneven water distribution in time and space, coupled with the limited infrastructure and the influence of complex topography, the use of water resources is difficult and costly, resulting in serious seasonal, regional, and engineering water shortages [36]. With the rapid population and economy growth, the demand for water resources in Southwest China continues to increase, and the misalignment between supply and demand is becoming increasingly acute. Therefore, we used a water resource accessibility index model considering five factors-runoff, slope, relative height difference, water intake distance and land use resistance-to evaluate the grid-scale water resource accessibility in Southwest China, using the ArcGIS platform (Environmental Systems Research Institute, Redlands, California, America) to construct the spatial pattern of water resource accessibility. Then, we analyzed the coupling coordination degree between water resource accessibility and eco-socio-economic water demand elements. The aims are to improve the water resource accessibility evaluation method, identify the areas with relatively low water resource accessibility and the key regions that the coupling coordination degree between water resource accessibility and eco-socio-economic water demand elements is relatively low, which is important for improving the determination of regional water resource security levels, strengthening regional water resource management allocation, and effectively implementing water conservancy facilities planning and urban development planning.

\section{Materials and Methods}

\subsection{Study Area}

The study area is located in Southwest China, including Chongqing Municipality, Sichuan Province, Guizhou Province, Yunnan Province, and the Guangxi Zhuang Autonomous Region, between $97^{\circ} 21^{\prime}-112^{\circ} 3^{\prime} \mathrm{E}$ and $20^{\circ} 53^{\prime}-34^{\circ} 18^{\prime} \mathrm{N}$ and covers a total area of 1.362 million $\mathrm{km}^{2}$ (Figure 1 ). Southwest China is one of the three karst-concentrated contiguous areas in the world; the terrain in the area is complex and diverse, and the landforms are mainly plateaus and mountains in which basins 
and hills are widely distributed. The altitude difference is large, and the average elevation is as high as $1700 \mathrm{~m}$. At the end of 2015, the region had a total resident population of 242.89 million, with an urbanization rate of $47.5 \%$, the gross domestic product (GDP) was 8669.52 billion yuan, and a farmland irrigation area was 7.86 million ha [37-41].

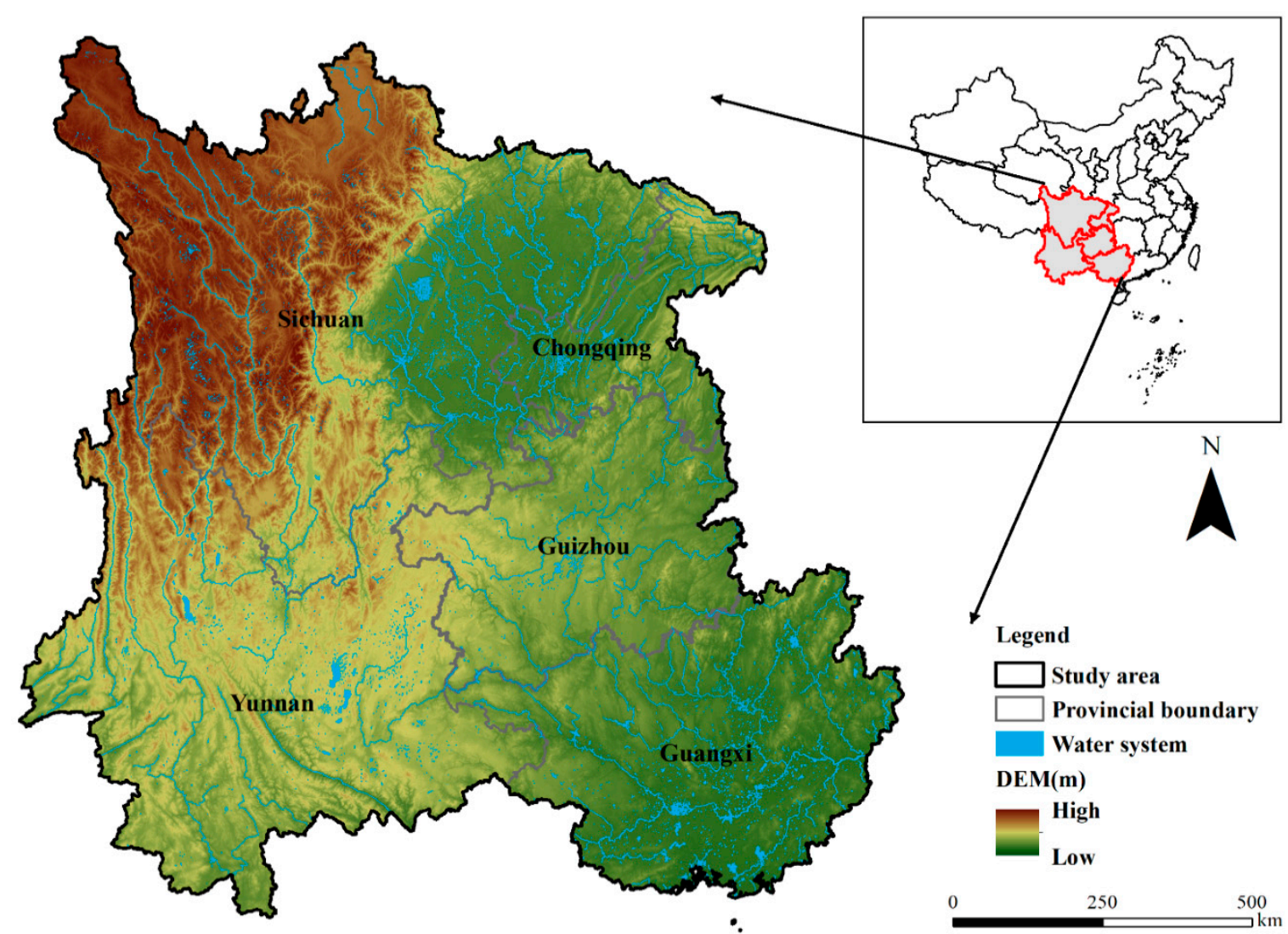

Figure 1. Location of study area in Southwest China (Note: The digital elevation model is abbreviated as DEM).

Southwest China is located in a tropical and subtropical humid region and is dominated by tropical and subtropical monsoon climates, with sufficient heat and abundant rainfall; however, rainfall is unevenly distributed in space and time. The region has developed water systems, including the Yangtze River, Yellow River, Irrawaddy River, Nujiang River, Lancang River, Yuanjiang River and Pearl River, which are the most important water resource enrichment areas in China [32]. In 2015, the average precipitation in the whole study area was $1211 \mathrm{~mm}$, the total water resources amounted to 813.59 billion $\mathrm{m}^{3}$, and the per capita water resource was $3350 \mathrm{~m}^{3}$. The annual water supply was 89.13 billion $\mathrm{m}^{3}$; and the agricultural, industrial, domestic, and ecological water consumptions were 54.31 billion $\mathrm{m}^{3}, 19.19$ billion $\mathrm{m}^{3}, 14.48$ billion $\mathrm{m}^{3}$, and 1.15 billion $\mathrm{m}^{3}$, respectively; but the water resource development use rate was only $11.0 \%$ [42-46], which is related to the difficulty in using water resources in the region [36].

\subsection{Data Sources}

Four main types of data sources were used in this study. Administrative boundary vector data, water system vector data, and digital elevation model $(30 \times 30 \mathrm{~m})$ were downloaded from Institute of Remote Sensing and Digital Earth, Chinese Academy of Sciences [47]. The land use type $(30 \times 30 \mathrm{~m})$ and the normalized vegetation index $(1000 \times 1000 \mathrm{~m})$ were derived from Resource and Environment Data Cloud Platform, Chinese Academy of Sciences [48]. The meteorological and hydrological data were sourced from National Meteorological Information Center [49], in which the 
runoff coefficient was derived from the water resource bulletin of each province (municipality and autonomous region) [42-46]. Socioeconomic data (GDP, population, food production) were derived from the statistical yearbooks of provinces (municipality and autonomous region) [37-41]. The spatial data coordinate system had a unified projection of WGS_1984_Albers, and the resolution after data resampling was $90 \times 90 \mathrm{~m}$.

\subsection{Methods}

\subsubsection{Basic Theory and Hypothesis}

Water resource accessibility is closely related to a series of natural and human factors. These natural factors mainly include the water source, distance, relative height difference, slope, and land use type, whereas human factors mainly include funds (income, water fee), infrastructure (water supply pipelines, waterworks), and technology (irrigation technology, water treatment technology). In this study, rivers, lakes, and reservoirs were selected as the main water sources. We assumed that water users collect water from the nearest water source, and the water resource accessibility is mainly affected by natural factors such as runoff, water intake distance, relative height difference, slope, and land use type, and ignoring human factors. Considering the amount of water is still a problem in Southwest China, and incorporating water quality elements would increase the calculation and interpretation complexity, the water quality was not measured.

Different spatial resistance factors have significant impacts on the amount of accessible water and the difficulty in obtaining water. The runoff is positively correlated with the water resource accessibility: The greater the runoff, the greater the available water, and the higher the water resource accessibility. The other factors (slope, water intake distance, relative height difference, and land use resistance) are negatively correlated with the water resource accessibility: The larger the factors, the greater the water intake difficulty, and the lower the water resource accessibility. The calculation methods of each spatial element index in this study are as follows: (1) Runoff. We first selected the rainfall data of the main meteorological stations in the study area to interpolate the rainfall. Then, we calculated the runoff by combining the spatial distribution of the average runoff coefficient of each administrative unit and the rainfall. (2) Water intake distance. We used the Euclidean tool in ArcGIS software (Environmental Systems Research Institute, Redlands, California, America) to calculate the distance from each grid unit to the water source. (3) Slope. We used the Slope tool in ArcGIS software (Environmental Systems Research Institute, Redlands, California, America) to calculate the slope of each grid unit. (4) Relative height difference. We first used the Mask tool in the ArcGIS software (Environmental Systems Research Institute, Redlands, California, America) to extract the elevation of the water system in the study area. Then, we used the Euclidean Allocation tool to assign the water system elevation to the nearest grid cell. Finally, the Raster Calculator tool was used to calculate the relative height difference between the elevation value of each grid cell and the water system elevation. The spatial factor resistance was referenced from the literature [50] (Table 1).

Different eco-socio-economic factors have different spatial impacts on water demand. Four factors at the county level-normalized difference vegetation index (NDVI), per capita GDP, population density, and grain yield per unit area-were selected to reflect the spatial characteristics of water demand, which were used to characterize ecological water demand, industrial water demand, domestic water demand, and agricultural water demand, respectively. Among them, the NDVI was obtained by mask extraction and zonal statistics of national data, per capita GDP, population density, and grain yield per unit area were calculated based on statistical data. All data for each indicator in this study were converted to dimensionless using the maximum difference normalization method before calculation. 
Table 1. Resistance classification and assignment of different spatial elements.

\begin{tabular}{ccc}
\hline Spatial Element & Grade & Resistance Value \\
\hline \multirow{3}{*}{ Relative height difference $(\mathrm{m})$} & -5050 to 0 & 1 \\
& $0-287$ & 3 \\
& $287-746$ & 5 \\
& $746-1420$ & 7 \\
Slope $\left({ }^{\circ}\right)$ & $1420-7122$ & 9 \\
& -90 to 01 & 1 \\
& $0-5$ & 5 \\
& $5-15$ & 7 \\
\hline \multirow{2}{*}{ Land use type } & $15-25$ & 9 \\
& $25-90$ & 1 \\
& Transportation land, grassland, green land, farmland & 3 \\
& Woodlands, garden & 5 \\
& Residential land, industrial and mining land & 7 \\
& Swamp, glaciers, bare land & 9 \\
\hline
\end{tabular}

${ }^{1}$ When the relative height difference is negative, the slope value is also negative, and the spatial resistance is smaller.

\subsubsection{Water Resource Accessibility Index Model}

We selected the runoff in each grid unit to represent the attractiveness of a water source to water users, and selected the cost distance constrained by the three resistance factors of slope, relative height difference, and land use to reflect the spatial resistance. Among them, runoff is positively correlated with water resource accessibility: The greater the runoff, the higher the accessibility. The cost distance is negatively correlated with the water resource accessibility: The larger the cost distance, the greater the accessibility. The cost distance can be determined using the cost distance model in ArcGIS software (Environmental Systems Research Institute, Redlands, California, America), which requires the input of two raster layers: The target layer and the resistance layer. In this study, the target layer was the water source (water system), whereas the resistance layer was the resistance matrix of three spatial factors: Slope, relative height difference, and land use type. According to the research [18,51], the water resource accessibility index model is as follows:

$$
A_{i}=W_{j} \times f \min \left(\sum_{j=i, m}^{i=1, n} D_{i j} \times R_{i}\right)
$$

where $A_{i}$ refers to the water resource accessibility index, $W_{j}$ refers to the water source attraction capacity (runoff), $f$ is a positive correlation function that reflects the relationship between the minimum cumulative resistance and the spatial resistance from the water users to the water source, and $D_{i j}$ and $R_{i}$ refer to the distance and space resistance from the water users to the water source, respectively.

\subsubsection{Coupling Coordination Degree Model}

Coupling refers to the phenomenon by which two or more systems interact with each other to achieve synergy, and the coupling coordination degree refers to the degree of coordinated development between two or more systems [52]. Water resource accessibility and eco-socio-economic water demand elements are two closely related systems that restrict and promote each other. Thus, we used a coupling coordination degree model to express the degree of coordinated development between the two systems. The equations are as follows [53-55]:

$$
\begin{gathered}
C=2 \sqrt{f(a) \times g(b)} /[f(a)+g(b)] \\
T=\alpha f(a)+\beta g(b)
\end{gathered}
$$




$$
D=\sqrt{C \times T}
$$

where $C$ refers to the coupling degree, with a value in the interval $[0,1] ; f(a)$ refers to the water resource accessibility; $g(b)$ refers to eco-socio-economic water demand elements; $D$ refers to the coupling coordination degree, with a value in the interval $[0,1]$ where the greater the $D$ value, the higher the coupling coordination degree of the two systems, and vice versa; $T$ refers to the comprehensive coordination index; $\alpha$ and $\beta$ refer to the contribution of water resource accessibility and eco-socio-economic water demand elements to the coupling coordination degree, respectively. According to related research [53-55], we selected $\alpha=\beta=0.5$ and divided the coupling coordination degree into 10 stages (Table 2).

Table 2. Classification standard and the types of coupling coordination degree (D).

\begin{tabular}{ccc}
\hline Category & D Value & Subclass \\
\hline \multirow{3}{*}{ Coordination category } & $0.9-1$ & Extreme coordination \\
& $0.8-0.9$ & High coordination \\
& $0.7-0.8$ & Moderate coordination \\
Transition category & $0.6-0.7$ & Low coordination \\
\hline \multirow{2}{*}{ Incoordination category } & $0.5-0.6$ & Reluctant coordination \\
& $0.4-0.5$ & Near incoordination \\
\hline & $0.3-0.4$ & Slight incoordination \\
& $0.2-0.3$ & Moderate incoordination \\
& $0.1-0.2$ & High incoordination \\
& $0-0.1$ & Extreme incoordination \\
\hline
\end{tabular}

\section{Results}

\subsection{Spatial Pattern of Water Resource Accessibility}

The spatial distribution characteristics of five factors-relative height difference, slope, land use resistance, water intake distance, and runoff-were analyzed. The relative height difference varies obviously. Extremely high mountains, such as Minshan, Nushan, and Hengduan Mountains, are concentrated in West Sichuan (in some areas, due to the existence of plateau lakes, the relative height difference is a large negative value) and West Yunnan, and the relative height difference is large, whereas the relative height differences in the Sichuan Basin, Guangxi, and Guizhou are relatively small (Figure 2a). The steep slope areas in the study area are relatively large, mainly distributed in West Sichuan and Northwest Yunnan, whereas the Sichuan Basin, Southwest Guangxi, and East Yunnan have relatively flat terrain with relatively low spatial resistance (Figure 2b). The concentrated distribution of glaciers and marshes in West Sichuan leads to a relatively high resistance value of land use in the region. In the Sichuan Basin and Northwest Sichuan, grassland, green land, and farmland are widely distributed, so the spatial resistance is relatively low (Figure 2c). The water intake distance is closely related to the spatial distribution of the water system. The water systems in Southwest Yunnan, North-Central Sichuan, and Guizhou are sparse, and the water intake distance is relatively large (Figure 2d). Due to the differences in the precipitation, temperature, and underlying surface of the watershed, and the influence of human activities, the regional differences in runoff are significant. The runoff is relatively high in East Guangxi and relatively low in the Sichuan Basin, West Sichuan, and Central and North Yunnan, whereas the overall trend is decreasing from the Southeast to the Northwest (Figure 2e). 

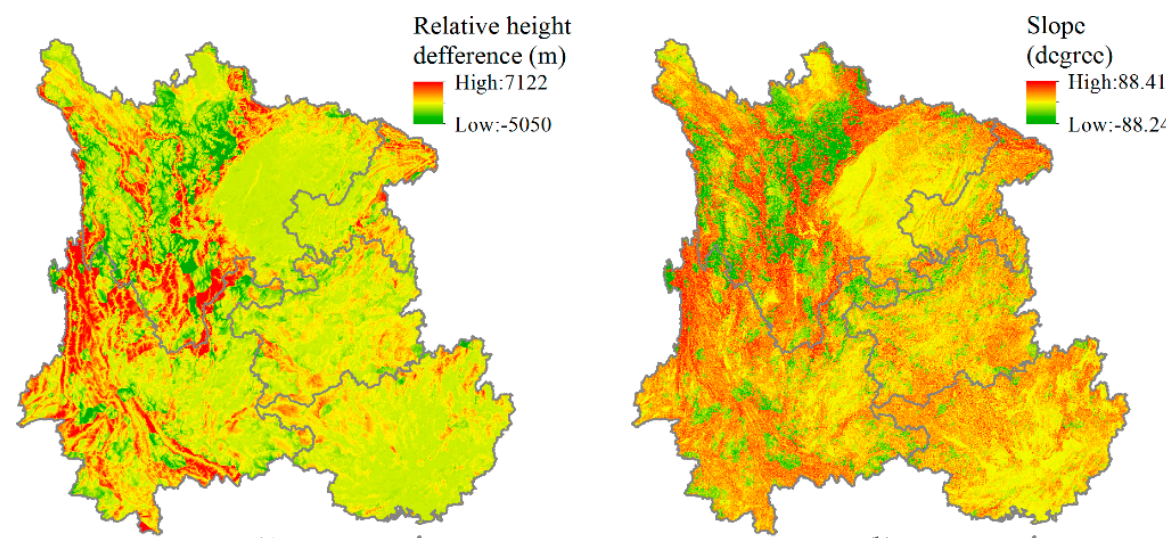

(a)

(b)
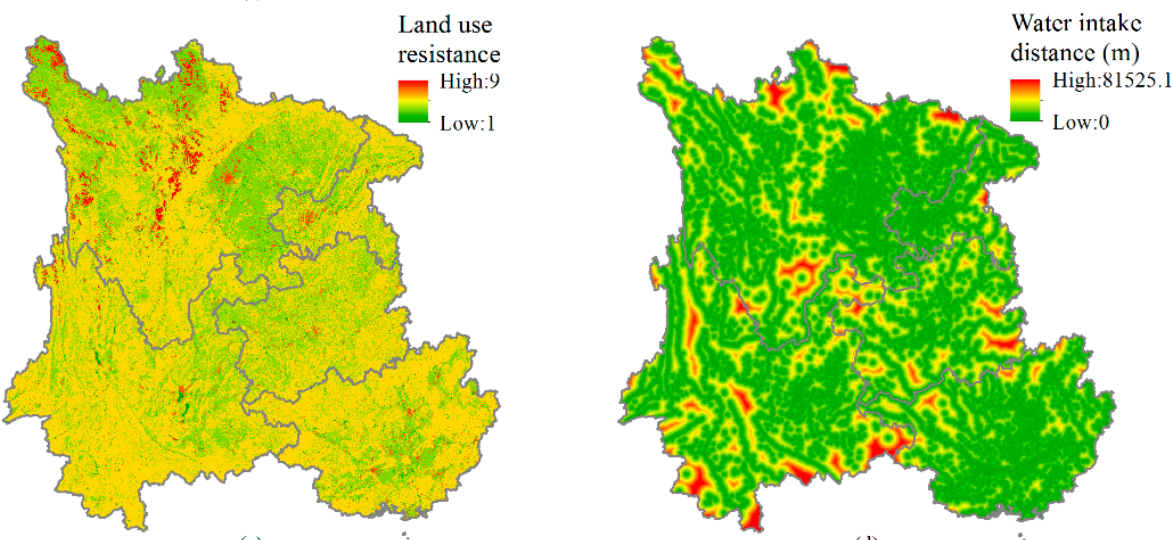

(c)

(d)

Runoff $\left(\mathrm{m}^{3}\right)$

IIigh: 15016.2

Low: 1813.98

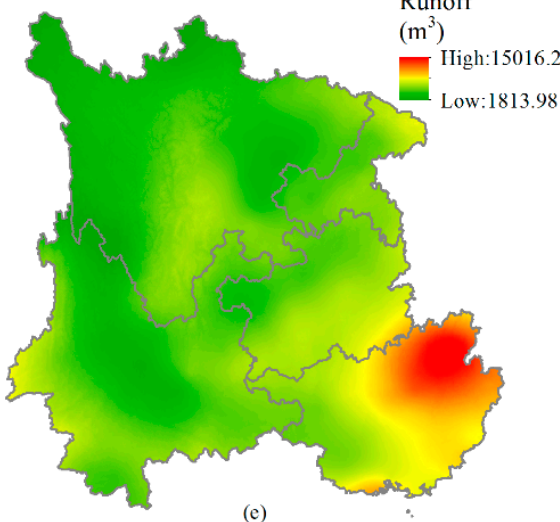

(e)

Figure 2. Spatial distribution of different factors affecting water resource accessibility: (a) Relative height difference, (b) slope, (c) land use, (d) water intake distance, and (e) runoff.

The grid-scale water resource accessibility has obvious regional differences, and the overall trend gradually decreases from Southeast to Northwest (Figure 3). The high-value area is mainly concentrated in Northeast Guangxi, whereas the low-value areas are mainly concentrated in West Sichuan and North-Central Yunnan, which is closely related to the spatial distributions of the water system, slope, elevation, runoff, and land use in Southwest China. In the Southeast, especially the Guangxi Zhuang Autonomous Region, the geomorphological type is a mountainous and hilly basin, and the terrain is relatively flat, whereas spatial resistance, such as the slope and relative height difference, is relatively low. The water system in the region is well-developed and the runoff is relatively high, with fewer constraints on access to water resources, so the water resource accessibility is relatively high. However, in the Northwest, especially in West Sichuan and Northwest Yunnan, the wide distribution of extremely high mountains, glaciers, and swamps results in a significant elevation difference, a large slope and land use resistance in the region, coupled with the relatively sparse water system and fewer water 
resources, which considerably increase the difficulty in obtaining water resources, resulting in relatively low water resource accessibility.

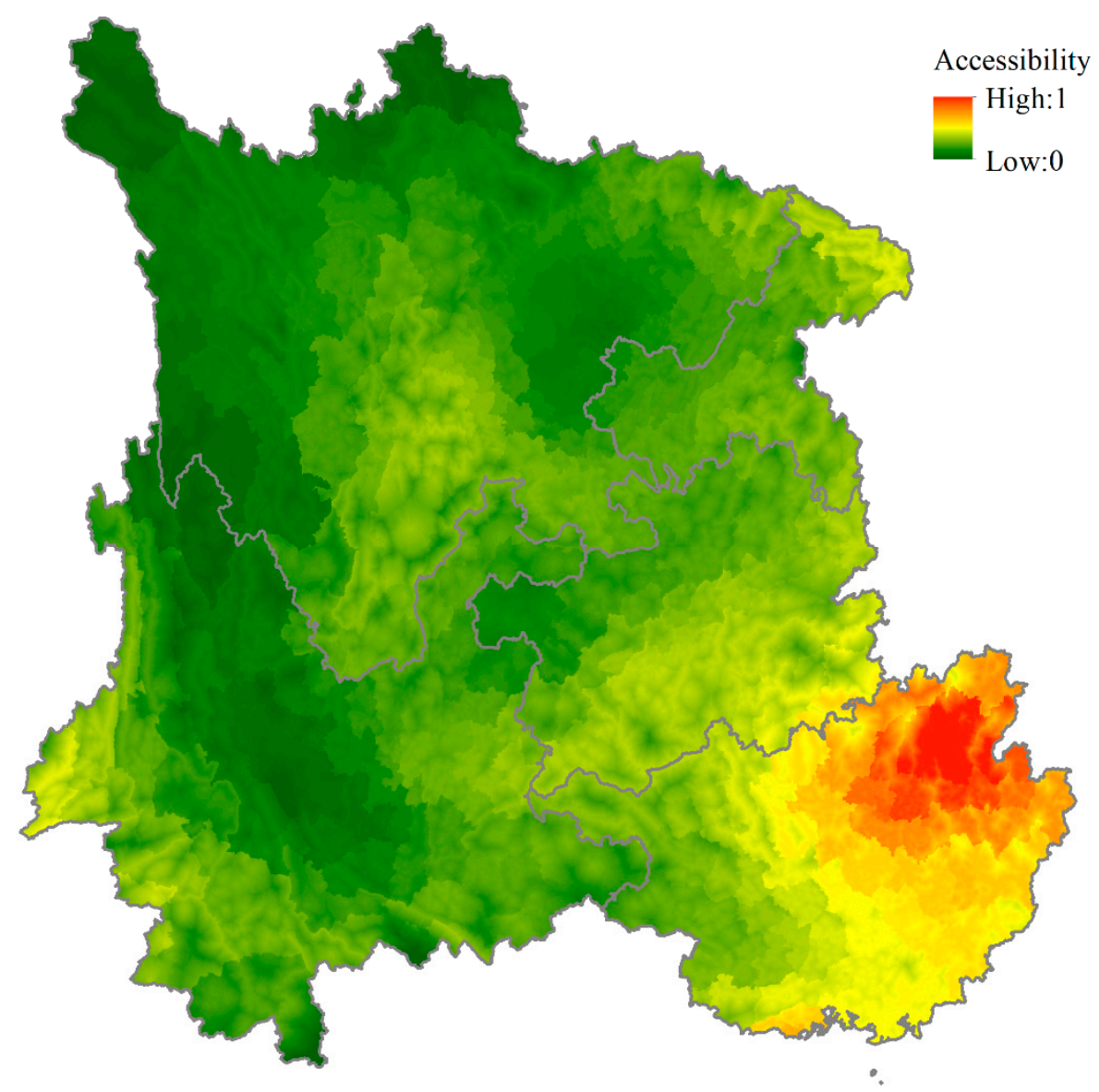

Figure 3. The spatial pattern of the water resource accessibility in Southwest China at the grid-scale.

Taking the county-level administrative district as the statistical unit, the water resource accessibility at the grid cell was calculated, and the spatial pattern of water resource accessibility at the county level was determined (Figure 4). The water resource accessibility varies considerably between different counties (districts) in Southwest China. The counties (districts) with relatively high water resource accessibility are mainly concentrated in Northeast Guangxi, whereas the water resource accessibility in some counties (districts) in the Sichuan Basin, West Sichuan, and Central and North Yunnan is relatively low, and the overall trend is a gradual decrease from Southeast to Northwest. The maximum water resource accessibility value was 0.996 in the Qixing District of Guangxi Zhuang Autonomous Region, and the lowest value was 0.113 in Derong County, Sichuan Province. 


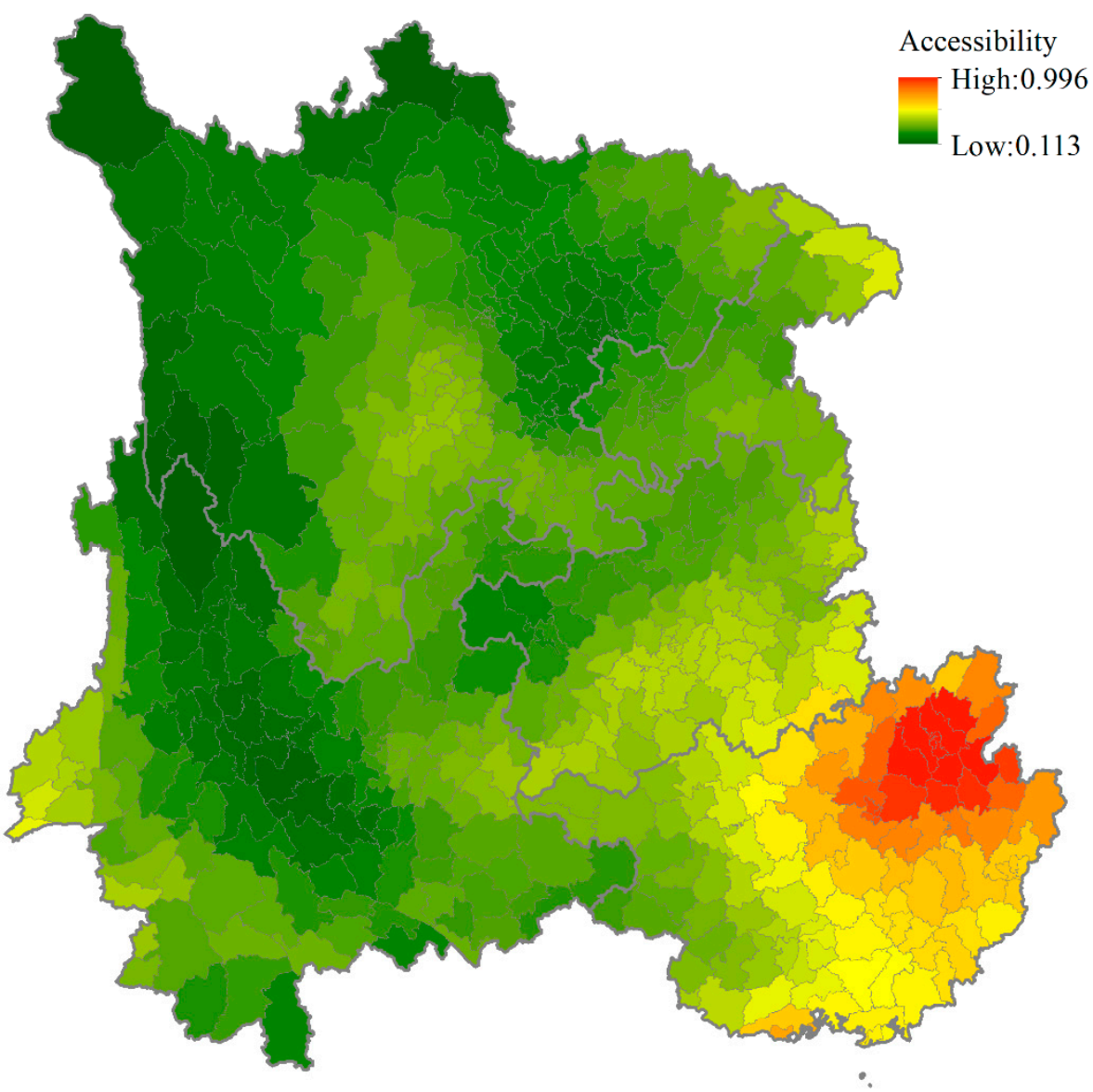

Figure 4. The spatial pattern of water resource accessibility in Southwest China at the county scale.

\subsection{Spatial Distribution Characteristics of Different Water Demand Elements}

In the study area, the superior hydrological and climatic conditions provide a suitable environment for the growth of vegetation, which increases the vegetation index overall. Only a few counties (districts) in West Sichuan and the urban center areas of each province (municipality and autonomous region) have relatively low NDVI scores (Figure 5a). As a typical ethnic minority settlement in China, Southwest China has a developing economy, and there is a significant difference in per capita GDP between different counties (districts) (Figure 5b). Among them, the per capita GDP in Central Sichuan, West Chongqing, and the urban center area of each province (municipality and autonomous region) is relatively high, and the per capita GDP in West and Northeast Sichuan, East Guizhou, Northwest Guangxi, and most parts of Yunnan is relatively low. The counties (districts) with high population density in the study area are mainly concentrated in the Sichuan Basin and the urban centers of each province (municipality and autonomous region) (Figure 5c). These regions have rapid economic development and a high level of urbanization, providing superior conditions for human survival and development. The low-value areas are mainly distributed in the ethnic minority areas of West Sichuan, West Yunnan, Southeast Guizhou, and Northwest Guangxi. East Sichuan, West Chongqing, Northeast Yunnan, and East Guangxi have flat terrain, superior climate and hydrological conditions, and the grain yield per unit area is relatively high (Figure 5d). In West Sichuan, Northwest Yunnan, and Guizhou, widespread mountainous areas, water shortages, and extensive desertification seriously affect food production. 


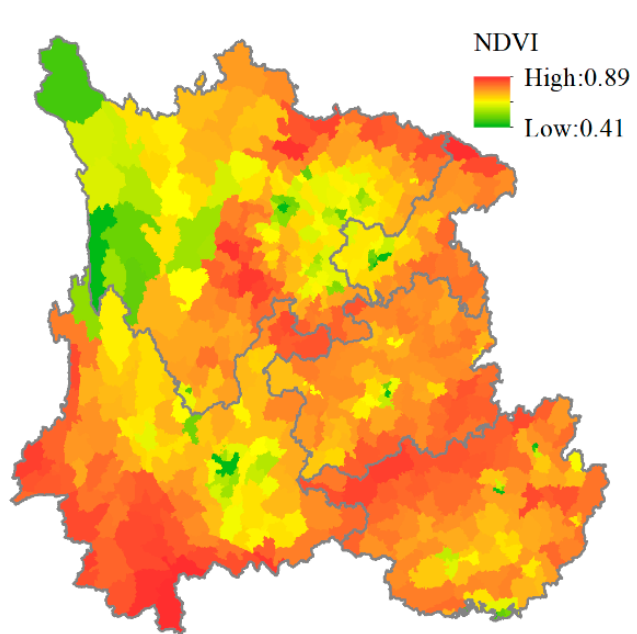

(a)

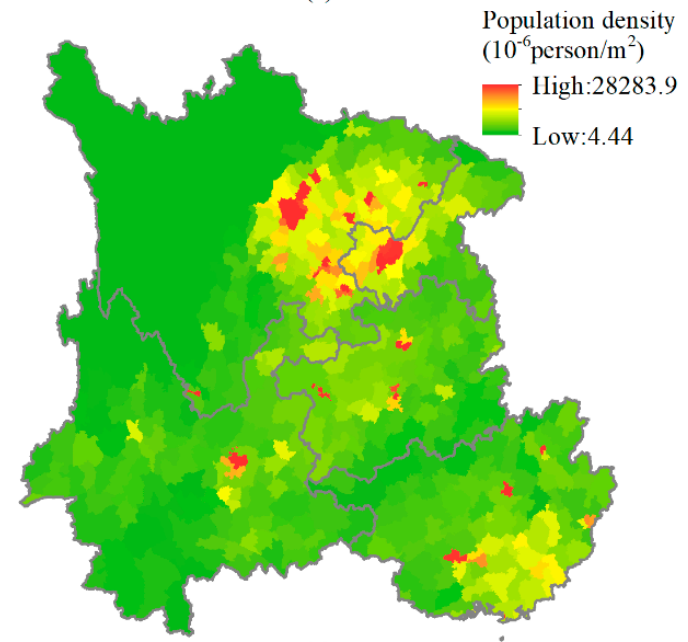

(c)

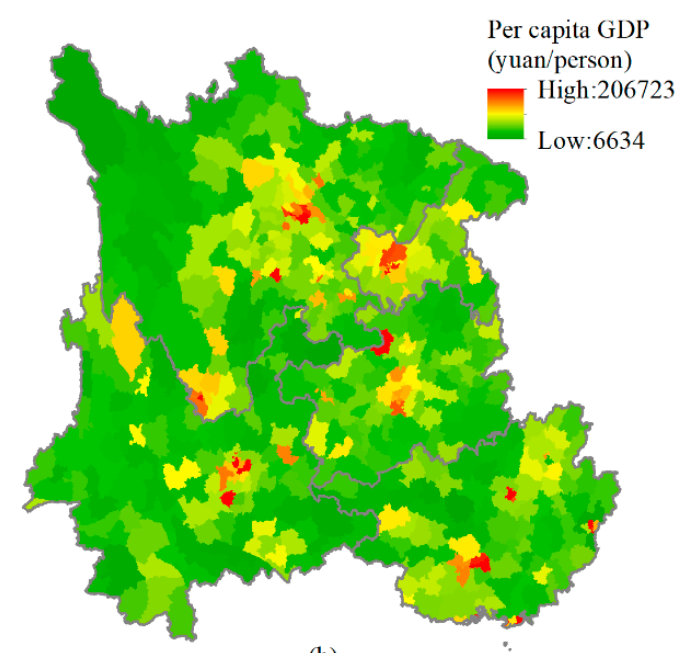

(b)

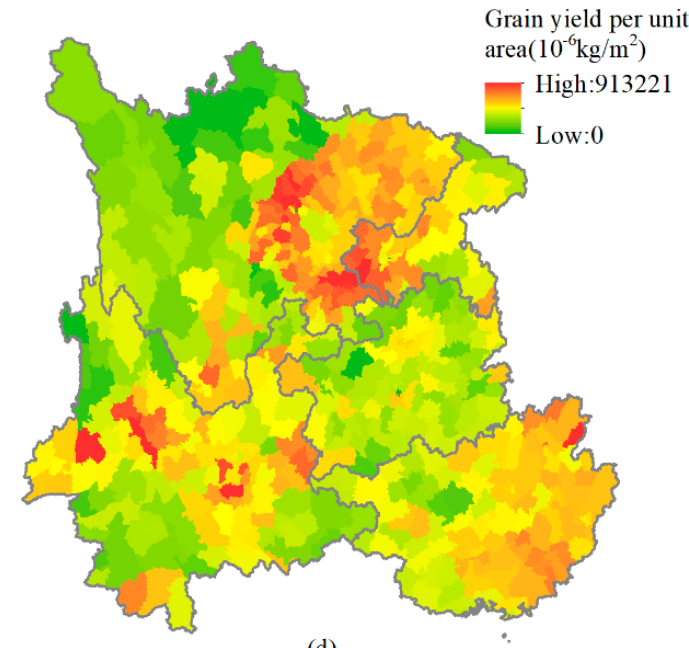

(d)

Figure 5. The spatial distribution of different eco-socio-economic water demand elements at the county level: (a) Normalized difference vegetation index (NDVI), (b) per capita GDP, (c) population density, (d) grain yield per unit area.

To more accurately reflect the water demand characteristics of each county (district) in Southwest China, the different water demand elements of each county-level administrative unit were weighted and summed according to the proportion of the water resource use structure for each province (municipality and autonomous region) in 2015; then, the spatial distribution of the comprehensive water demand elements in Southwest China was determined (Figure 6). The counties (districts) with high water resource demand are mainly concentrated in the Sichuan Basin, East Guangxi, and Central Yunnan, where the agricultural production level is relatively high, economic development is relatively fast, and the population is relatively concentrated. West Sichuan, Northwest Yunnan, and Guizhou, where agricultural production and the population density are low and economic development is relatively slow, have a lower water demand. 


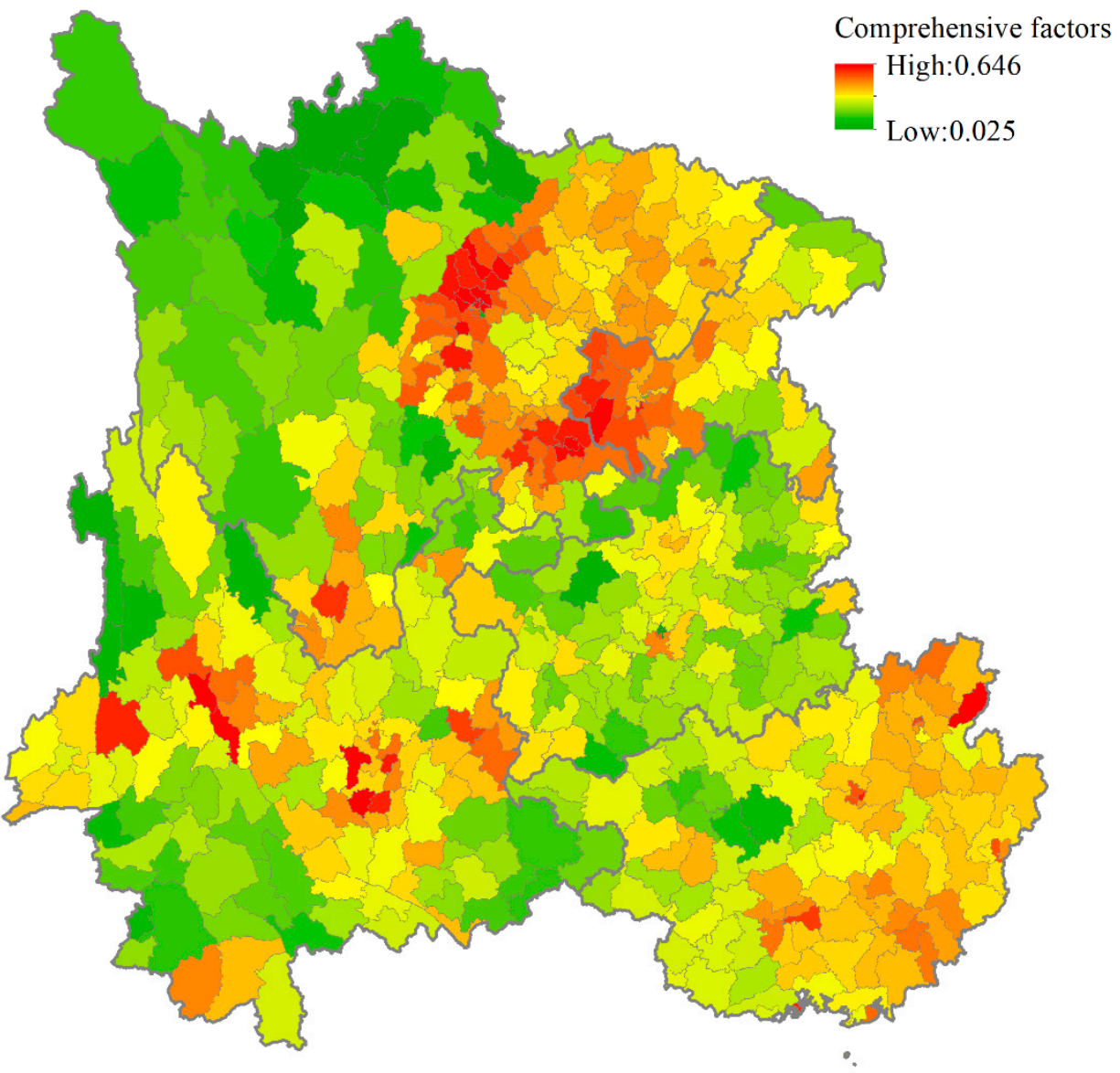

Figure 6. The spatial distribution of comprehensive water demand elements at the county level.

\subsection{Coupling Coordination Degree of Water Resource Accessibility and Water Demand Elements}

The coupling coordination degree of water resource accessibility and eco-socio-economic water demand elements in Southwest China was between 0.26 and 0.84 , showing significant regional differences (Figure 7). The coupling coordination degree in Northeast Guangxi is relatively high overall, whereas the coupling coordination degree in West and North Sichuan and Northwest Yunnan, is relatively low. The overall trend is a decrease from Southeast to Northwest. The highest is Diecai District, Guangxi Zhuang Autonomous Region, and the lowest is Hongyuan County, Sichuan Province. According to the statistical results, the coupling coordination degree of water resource accessibility and eco-socio-economic water demand elements in the study area are mainly distributed in the coordination and transition stages, among which 5 counties (districts) show high coordination, accounting for $0.92 \%$; 29 counties (districts) show moderate coordination, accounting for $5.31 \% ; 115$ counties (districts) show low coordination, accounting for $21.06 \% ; 326$ counties (districts) show reluctant coordination, accounting for $59.71 \%$; and 68 counties (districts) show near incoordination, accounting for $12.45 \%$; 2 counties show reluctant coordination, accounting for $0.37 \%$; and 1 counties show near incoordination, accounting for $0.18 \%$. The coupling coordination degree of water resource accessibility and eco-socio-economic water demand elements in Southwest China is relatively low overall. 


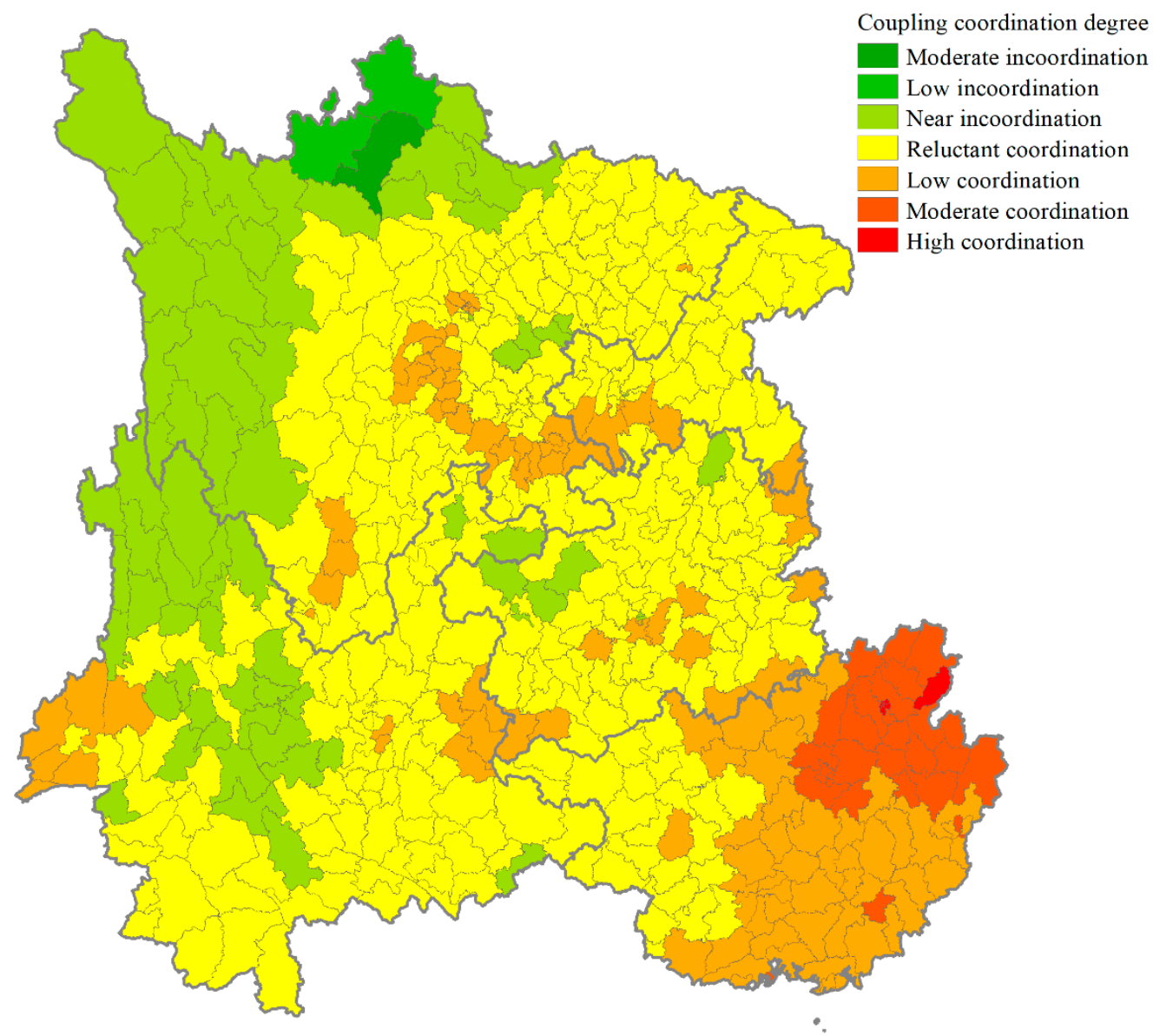

Figure 7. Spatial distribution of coupling coordination degree between water resource accessibility and water demand elements.

The regional difference in the coupling coordination degree between water resource accessibility and eco-socio-economic water demand elements in Southwest China are mainly due to the spatial differences in hydrological conditions, topography, and economic development level. East Guangxi has a relatively flat terrain, superior natural conditions, relatively low spatial resistance, and abundant precipitation, so the water resource accessibility is relatively high, which guarantees good growth and the efficient production of rice and other crops. East Guangxi is also the economic development center of Guangxi Zhuang Autonomous Region, and the population is highly concentrated, resulting in high water resource demand. Therefore, the water resource accessibility and the eco-socio-economic water demand elements show a relatively high coordinated development. The Sichuan Basin is one of the most important grain production bases in China. It has a relatively dense population and rapid economic development. However, due to the small amount of water resources and relatively low water resource accessibility, which lead to limited eco-socio-economic sustainable development to a certain extent, the coupling coordination degree between the two is relatively low. In Northwest Yunnan and West and North Sichuan, the wide distribution of extremely high mountains has caused large altitude differences and steep slopes, coupled with a relatively sparse water system and a low amount of water resources, so water resource accessibility in the region is extremely low, which means that it is difficult to meet the water resource demand of the eco-socio-economic elements. Therefore, the coupling coordination degree between the water resource accessibility and eco-socio-economic water demand elements shows near incoordination. 


\section{Discussion}

\subsection{Evaluation Method of Water Resource Accessibility}

Water resource accessibility refers to the difficulty in obtaining water resources from water sources and is affected by multiple factors such as water quality, water quantity, distance, elevation, slope, land use, capital, infrastructure, and technology. Among them, the quantity and quality of water resources are decisive factors for the availability of water resources, whereas the distance, altitude, slope, land use, and others are factors affecting the convenience of obtaining water resources. The existing quantitative analyses of water resource accessibility often involved a single indicator or a few factors. For example, Jeff et al. [9] only considered the linear distance to the water source. Smiley [56] selected the four elements of water quality, water cost, water reliability, and water intake burden, and measured water resource accessibility through questionnaires and statistical analysis. Yu et al. [28] selected four factors including the slope, relative height difference, distance, and runoff to comprehensively analyze the accessibility of river water resources in the Hanjiang River Basin. Li et al. [29] constructed a grid-scale water accessibility evaluation model based on the length, runoff and viewshed value. Li et al. [57] constructed a water accessibility index by selecting indicators such as distance, altitude, ditch density, road density, and culvert number to study the water resource accessibility of freshwater wetland. In this study, we evaluated water resource accessibility by considering the five factors of runoff, slope, relative height difference, water intake distance, and land use resistance, and analyzed the spatial pattern of the water resource accessibility in different grid units. Among them, water quantity represents the attractiveness of the water source to the water users, and the other factors reflect the spatial resistance.

However, the water resource accessibility evaluation in this study still has some room for improvement. First, our evaluation only considered the impact of water quantity and ignored the water quality. Thus, in future research, the quality of water resources should be measured in terms of water quality requirements for different water demand elements. Second, we assumed that water users obtain water from the closest water source, but in practice, multiple water sources provide water for users. Therefore, it is necessary to weight the multiple water sources within a certain range in future research. Third, we ignored the impact of socio-economic factors, such as water supply facilities, water treatment technology, irrigation technology, and water fees, on water resource accessibility, which affects the accuracy of the evaluation results to a certain extent; thus, future research needs to comprehensively measure multiple factors.

\subsection{Water Resource Accessibility and Regional Eco-Socio-Economic Development}

Water resources are an important basis for supporting the development of eco-socio-economic systems, whereas social and economic development provides the necessary funds and conditions for ensuring the sustainable development and use of water resources [58], which affect and restrict each other. The limited water resource accessibility of spatial units not only threatens the supply of drinking water and irrigation water, but also threatens the sustainable and healthy development of the ecosystem $[20,59,60]$. Therefore, spatially accessible water resources are essential for an adequate freshwater supply [28].

In Southwest China, the topography and geomorphology are particularly complex, the spatial-temporal distribution of water resources is uneven, and the water supply facilities lack expansion and improvement potential, resulting in serious seasonal, regional, and engineering water shortages. The use of water resources is difficult and costly, which seriously restricts regionally sustainable eco-socio-economic development. Therefore, water resource management in Southwest China must fully consider the characteristics and formation of water resources in the region and should adopt different water resource development and use models. The analysis of the coupling coordination degree between water resource accessibility and eco-socio-economic water demand elements can be used to effectively identify the areas where the coupling coordination degree between the two is 
relatively low. This can provide a decision-making basis for strengthening regional water resource management and allocation, for effectively implementing water conservancy facilities planning, and for urban development planning, thus ensuring the coordinated and sustainable development of various systems.

In West Sichuan and Northwest Yunnan, there are many extremely high mountains, resulting in significant altitude differences and steep slopes, and the water sources are far away from water users, so the water resource accessibility is low and agricultural irrigation is difficult. Therefore, these areas require more investment to improve irrigation conditions and increase irrigation efficiency to meet crop water requirements. In the Sichuan Basin, Central Yunnan, Northwest Guizhou, and Southeast Guangxi, the population density is relatively high; it is necessary to continuously strengthen water resource protection and infrastructure construction in densely populated areas to ensure a safe and adequate supply of drinking water. The economic development level of most counties (districts) in Southwest China is low, somewhat lagging behind the water resource accessibility level, whereas the water resource accessibility in West Sichuan and Northwest Yunnan is relatively low, which restricts economic development to some extent. Therefore, according to the spatial pattern of water resource accessibility, rationally adjusting the industrial structure and developing a circular economy is necessary, which contribute to promoting rational and rapid economic development and ensuring the coordinated development of water resource accessibility and social and economic elements. In Northwest Yunnan and West and Northeast Sichuan, relatively poor natural conditions and scarce water resources result in relatively low water resource accessibility, which considerably limits vegetation growth. Therefore, these regions should be the focus for ecological conservation and restoration.

\section{Conclusions}

This paper applied a water resource accessibility index model, considering five spatial factors of runoff, slope, relative height difference, water intake distance and land use resistance, which enabled the quantitative analysis of the spatial distribution characteristics of water resource accessibility on a grid-scale in Southwest China. The results show that due to the large spatial distribution differences of different spatial elements, the spatial differences in water resource accessibility in Southwest China are relatively significant, and the overall trend is a decrease from Southeast to Northwest.

Due to the differences in hydrological conditions, topography, and economic development level, the coupling coordination degree between water resource accessibility and eco-socio-economic water demand elements in Southwest China has obvious regional differences, and the overall distribution characteristics are higher in the Southeast and lower in the Northwest. The proportion of counties (districts) with moderate coordination or higher was only 6.23\%, mainly concentrated in the Northeast part of Guangxi. The counties (districts) with near incoordination, low incoordination, and moderate incoordination accounted for $13.00 \%$, mainly concentrated in West Sichuan and Northwest Yunnan. The coupling coordination degree between the two is relatively low overall.

The water resource accessibility and the eco-socio-economic system in Southwest China have not achieved coordinated or sustainable development. The insufficient water resource support capacity in the region has restricted the development of the region to a certain extent, and the rapidly increasing population and economic development have increased water supply stress to a certain extent. Therefore, it is necessary to continuously coordinate the relationship between water resource management and regional development.

Author Contributions: Conceptualization, H.D.; Data curation, T.L., S.Q., S.M. and R.B.; Formal analysis, T.L.; Investigation, T.L., S.Q., S.M. and R.B.; Methodology, T.L., S.Q. and H.D.; Project administration, H.D.; Visualization, T.L.; Writing—original draft, T.L.; Writing—review \& editing, T.L., S.Q., S.M., R.B. and H.D.

Funding: This research was funded by the National Key Research and Development Program of China (No. 2016YFC0502106).

Acknowledgments: We thank Yuebo Su for help and advice in data processing, article writing and modification. 
Conflicts of Interest: The authors declare no conflict of interest.

\section{References}

1. Liquete, C.; Maes, J.; La Notte, A.; Bidoglio, G. Securing water as a resource for society: An ecosystem services perspective. Ecohydrol. Hydrobiol. 2011, 11, 247-259. [CrossRef]

2. Zhang, J.; Chen, G.; Xing, S.; Shan, Q.; Wang, Y.; Li, Z. Water shortages and countermeasures for sustainable utilisation in the context of climate change in the Yellow River Delta region, China. Int. J. Sustain. Dev. World Ecol. 2011, 18, 177-185. [CrossRef]

3. Vorosmarty, C.J.; McIntyre, P.B.; Gessner, M.O.; Dudgeon, D.; Prusevich, A.; Green, P.; Glidden, S.; Bunn, S.E.; Sullivan, C.A.; Liermann, C.R.; et al. Global threats to human water security and river biodiversity. Nature 2010, 467, 555-561. [CrossRef] [PubMed]

4. Lopez-Moreno, J.I.; Zabalza, J.; Vicente-Serrano, S.M.; Revuelto, J.; Gilaberte, M.; Azorin-Molina, C.; Moran-Tejeda, E.; Garcia-Ruiz, J.M.; Tague, C. Impact of climate and land use change on water availability and reservoir management: Scenarios in the Upper Aragon River, Spanish Pyrenees. Sci. Total Environ. 2014, 493, 1222-1231. [CrossRef] [PubMed]

5. Martinez-Santos, P.; Cervan, J.A.; Cano, B.; Diaz-Alcaide, S. Water versus Wireless Coverage in Rural Mali: Links and Paradoxes. Water 2017, 9, 375. [CrossRef]

6. Mokssit, A.; de Gouvello, B.; Chazerain, A.; Figuères, F.; Tassin, B. Building a Methodology for Assessing Service Quality under Intermittent Domestic Water Supply. Water 2018, 10, 1164. [CrossRef]

7. Brown, C.M.; Lund, J.R.; Cai, X.M.; Reed, P.M.; Zagona, E.A.; Ostfeld, A.; Hall, J.; Characklis, G.W.; Yu, W.; Brekke, L. The future of water resources systems analysis: Toward a scientific framework for sustainable water management. Water Resour. Res. 2015, 51, 6110-6124. [CrossRef]

8. Yang, Z.; Zhao, Y.; Cui, B.; Hu, T. Ecocity-oriented water resources supply-demand balance analysis. China Environ. Sci. 2004, 24, 636-640. (In Chinese) [CrossRef]

9. Ho, J.C.; Russel, K.C.; Davis, J. The challenge of global water access monitoring: Evaluating straight-line distance versus self-reported travel time among rural households in Mozambique. J. Water Health 2014, 12, 173-183. [CrossRef]

10. Purshouse, H.; Roxburgh, N.; Javorszky, M.; Sleigh, A.; Kimani, D.; Evans, B. Effects of water source accessibility and reliability improvements on water consumption in eastern Nairobi. Waterlines 2017, 36, 204-215. [CrossRef]

11. Hu, Y.; Domns, J. Measuring and visualizing place-based space-time job accessibility. J. Transp. Geogr. 2019, 74, 278-288. [CrossRef]

12. Hansen, W.G. How Accessibility Shapes Land Use. J. Am. Inst. Plan. 1959, 25, 73-76. [CrossRef]

13. Ala-Hulkko, T.; Kotavaara, O.; Alahuhta, J.; Helle, P.; Hjort, J. Introducing accessibility analysis in mapping cultural ecosystem services. Ecol. Indic. 2016, 66, 416-427. [CrossRef]

14. Cascetta, E.; Cartenì, A.; Montanino, M. A behavioral model of accessibility based on the number of available opportunities. J. Transp. Geogr. 2016, 51, 45-58. [CrossRef]

15. Chen, Y.; Ravulaparthy, S.; Deutsch, K.; Dalal, P.; Yoon, S.Y.; Lei, T.; Goulias, K.G.; Pendyala, R.M.; Bhat, C.R.; $\mathrm{Hu}, \mathrm{H} . \mathrm{-H}$. Development of Indicators of Opportunity-Based Accessibility. Transp. Res. Rec. J. Transp. Res. Board 2011, 2255, 58-68. [CrossRef]

16. Páez, A.; Scott, D.M.; Morency, C. Measuring accessibility: Positive and normative implementations of various accessibility indicators. J. Transp. Geogr. 2012, 25, 141-153. [CrossRef]

17. Kwan, M.-P. Space-Time and Integral Measures of Individual Accessibility: A Comparative Analysis Using a Point-Based Framework. Geogr. Anal. 1998, 30, 191-216. [CrossRef]

18. Wang, Y.; Chen, B.; Yuan, H.; Wang, D.; Lam, W.K.H.; Li, Q. Measuring temporal variation of location-based ccessibility using spacetimeutility perspective. J. Transp. Geogr. 2018, 73, 13-24. [CrossRef]

19. Nastiti, A.; Sudradjat, A.; Geerling, G.W.; Smits, A.J.M.; Roosmini, D.; Muntalif, B.S. The effect of physical accessibility and service level of water supply on economic accessibility: A case study of Bandung City, Indonesia. Water Int. 2017, 42, 831-851. [CrossRef]

20. Biggs, E.M.; Duncan, J.M.A.; Atkinson, P.M.; Dash, J. Plenty of water, not enough strategy: How inadequate accessibility, poor governance and a volatile government can tip the balance against ensuring water security: The case of Nepal. Environ. Sci. Policy 2013, 33, 388-394. [CrossRef] 
21. Manandhar, S.; Pandey, V.P.; Kazama, F. Application of Water Poverty Index (WPI) in Nepalese Context: A Case Study of Kali Gandaki River Basin (KGRB). Water Resour. Manag. 2011, 26, 89-107. [CrossRef]

22. Dong, G.; Shen, J.; Jia, Y.; Sun, F. Comprehensive Evaluation of Water Resource Security: Case Study from Luoyang City, China. Water 2018, 10, 1106. [CrossRef]

23. Yan, Y.; Qian, Y.; Wang, Z.Y.; Yang, X.Y.; Wang, H.W. Ecological risk assessment from the viewpoint of surface water pollution in Xiamen City, China. Int. J. Sustain. Dev. World Ecol. 2018, 25, 403-410. [CrossRef]

24. Cai, J.; Varis, O.; Yin, H. China's water resources vulnerability: A spatio-temporal analysis during $2003-2013$. J. Clean. Prod. 2017, 142, 2901-2910. [CrossRef]

25. Rodrigues, D.B.B.; Gupta, H.V.; Mendiondo, E.M. A blue/green water-based accounting framework for assessment of water security. Water Resour. Res. 2014, 50, 7187-7205. [CrossRef]

26. Lester, S.; Rhiney, K. Going beyond basic access to improved water sources: Towards deriving a water accessibility index. Habitat Int. 2018, 73, 129-140. [CrossRef]

27. Kohli, A.; Komisar, S.J.; Montenegr, C.E. Maximizing domestic water accessibility: A statistical model. Desalination 2009, 248, 530-536. [CrossRef]

28. Yu, G.; Chen, X.; Tu, Z.; Yu, Q.; Liu, Y.A.; Yu, H. Modeling Water Accessibility of Natural River Networks Using the Fine-Grained Physical Watershed Characteristics at the Grid Scale. Water Resour. Manag. 2017, 31, 2271-2284. [CrossRef]

29. Li, F.; Liu, H.; Chen, X.; Yu, D. Trivariate Copula Based Evaluation Model of Water Accessibility. Water Resour. Manag. 2019, 33, 3211-3225. [CrossRef]

30. Crow, B.; Sultana, F. Gender, Class, and Access to Water: Three Cases in a Poor and Crowded Delta. Soc. Nat. Resour. 2002, 15, 709-724. [CrossRef]

31. Gedo, H.W.; Morshed, M.M. Inadequate accessibility as a cause of water inadequacy: A case study of Mpeketoni, Lamu, Kenya. Water Policy 2013, 15, 598-609. [CrossRef]

32. Smiley, S.L. Complexities of water access in Dar es Salaam, Tanzania. Appl. Geogr. 2013, 41, $132-138$. [CrossRef]

33. Sorenson, S.B.; Morssink, C.; Campos, P.A. Safe access to safe water in low income countries: Water fetching in current times. Soc. Sci. Med. 2011, 72, 1522-1526. [CrossRef] [PubMed]

34. Li, S. A preliminary study on spatial accessibility of Nanchang urban rivers based on nearest distance analysis. Jiangxi Hydraul. Sci. Technol. 2017, 43, 254-257. (In Chinese) [CrossRef]

35. Liu, G. Formation and evolution mechanism of ecological security pattern in Southwest China. Acta Ecol. Sin. 2016, 36, 7088-7091. (In Chinese) [CrossRef]

36. Wu, C.; Dery, S.; Wu, W.; Liu, X.; Xiong, J.; Gao, W. A review of water resources utilization and protection in Southwest China. Sci. Cold Arid Reg. 2015, 7, 736-746. [CrossRef]

37. Chongqing Municipal Bureau of Statistics. Chongqing statistical Yearbook 2016; China Statistics Press: Beijing, China, 2016. (In Chinese)

38. Guangxi Bureau of Statistics. Guangxi Statistical Yearbook 2016; China Statistics Press: Beijing, China, 2016. (In Chinese)

39. Guizhou Bureau of Statistics. Guizhou Statistical Yearbook 2016; China Statistics Press: Beijing, China, 2016. (In Chinese)

40. Sichuan Bureau of Statistics. Sichuan Statistical Yearbook 2016; China Statistics Press: Beijing, China, 2016. (In Chinese)

41. Yunnan Bureau of Statistics. Yunnan Statistical Yearbook 2016; China Statistics Press: Beijing, China, 2016. (In Chinese)

42. Water Resources Department of Chongqing Municipal. Chongqing Water Resources Bulletin 2015; Water Resources Department of Chongqing Municipal: Chongqing, China, 2015. (In Chinese)

43. Water Resources Department of Guangxi Zhuang Autonomous Region. Guangxi Water Resources Bulletin 2015; Water Resources Department of Guangxi Zhuang Autonomous Region: Nanning, China, 2015. (In Chinese)

44. Water Resources Department of Guizhou Province. Guizhou Water Resources Bulletin 2015; Water Resources Department of Guizhou Province: Guiyang, China, 2015. (In Chinese)

45. Water Resources Department of Sichuan Province. Sichuan Water Resources Bulletin 2015; Water Resources Department of Sichuan Province: Chengdu, China, 2015. (In Chinese)

46. Water Resources Department of Yunnan Province. Yunnan Water Resources Bulletin 2015; Water Resources Department of Yunnan Province: Kunming, China, 2015. (In Chinese) 
47. Institute of Remote Sensing and Digital Earth, Chinese Academy of Sciences. Available online: http://eds.ceode.ac.cn/sjglb/dataservice.htm (accessed on 10 August 2018).

48. Resource and Environmental Science Data Cloud Platform, Chinese Academy of Sciences. Available online: http://www.resdc.cn/ (accessed on 15 August 2018).

49. National Meteorological Information Center. Available online: http://data.cma.cn/data/detail/dataCode/A 0029.0001.html (accessed on 15 August 2018).

50. Ye, Y.; Su, Y.; Zhang, H.; Liu, K.; Wu, Q. Construction of an ecological resistance surface model and its application in urban expansion simulations. J. Geogr. Sci. 2015, 25, 211-224. [CrossRef]

51. Geurs, K.T.; van Wee, B.; Rietveld, P. Accessibility Appraisal of Integrated Land-Use-Transport Strategies: Methodology and Case Study for the Netherlands Randstad Area. Environ. Plan. B Plan. Des. 2016, 33, 639-660. [CrossRef]

52. Wang, S.; Lu, D.; Wang, Z. Analysis of Spatial Coupling of Urbanization and Ecological Environment in Central Plains Economic Region (CPER). J. Pingdingshan Univ. 2018, 33, 104-110. (In Chinese)

53. He, J.; Wang, S.; Liu, Y.; Ma, H.; Liu, Q. Examining the relationship between urbanization and the eco-environment using a coupling analysis: Case study of Shanghai, China. Ecol. Indic. 2017, 77, 185-193. [CrossRef]

54. Li, M.; Mao, C. Spatial-Temporal Variance of Coupling Relationship between Population Modernization and Eco-Environment in Beijing-Tianjin-Hebei. Sustainability 2019, 11, 991. [CrossRef]

55. Yao, L.; Li, X.; Li, Q.; Wang, J. Temporal and Spatial Changes in Coupling and Coordinating Degree of New Urbanization and Ecological-Environmental Stress in China. Sustainability 2019, 11, 1171. [CrossRef]

56. Smiley, S.L. Defining and measuring water access: Lessons from Tanzania for moving forward in the post-Millennium Development Goal era. Afr. Geogr. Rev. 2016, 36, 168-182. [CrossRef]

57. Li, H.; Fan, Y.; Gong, Z.; Zhou, D. Water accessibility assessment of freshwater wetlands in the Yellow River Delta National Nature Reserve, China. Ecohydrol. Hydrobiol. 2019. [CrossRef]

58. Yu, X.; Zhang, L.; Chen, X.; Yang, K.; Huang, Y. Analysis of Coupling and Coordinated Development Between Water Resources and Social Economy in Hubei Province. Resour. Environ. Yangtze Basin 2018, 27, 809-817. (In Chinese) [CrossRef]

59. Yu, Q.; Tu, Z.; Yu, G.; Xu, L.; Yang, D.; Yang, Y. Modelling the crop water-satisfied degree on the grid scale: A CropWRA model and the case study of Hanjiang River Basin, China. Agric. For. Meteorol. 2018, 262, 215-226. [CrossRef]

60. Meunier, S.; Manning, D.T.; Quéval, L.; Cherni, J.A.; Dessante, P.; Zimmerle, D. Determinants of the marginal willingness to pay for improved domestic water and irrigation in partially electrified Rwandan villages. Int. J. Sustain. Dev. World Ecol. 2019, 1-13. [CrossRef] 